Gu Songjie

\title{
An Analysis of Manhan huangyu shanhe diming kao 滿漢皇舆山河地名考 - A Bilingual Manchu and Chinese Study of Mountain and River Toponyms of the Imperial Territories
}

DOI 10.17816/wmo35206

Abstract: Manhan huangyu shanhe diming kao 滿漢皇輿山河地名考 “A Study of Mountain and River Toponyms of the Imperial Territories" is a Manchu and Chinese bilingual manuscript on geography in the collection of the National Library of China. It is a collection of toponyms covering the northeastern territory of the Qing and includes a brief description of the military achievements before the Manchu conquest of the central plains. In this paper I argue that this text is closely related to the Shengjing Jilin Heilongjiang deng chu biaozhu zhanji yutu 盛京吉林黑龍江等處標注戰跡䡖圖 “Map of Military Deeds in Shengjing, Jilin, Heilongjiang," and that its dating on the title page to the Qianlong gengchen nian 乾隆庚辰年 “White Dragon year of Qianlong (1760)” is not actually the date of this manuscript's composition. The phrase of huangyu (the imperial territories) refers in the context of this work to the territory of the Qing before 1644.

Key words: Man-Han huangyu shanhe diming kao, Shengjing Lilin Heilongjiang dengchu biaozhu zhanji yutu, Qianlong gengchen nian, Dachun

\section{Introduction}

The Manhan huangyu shanhe diming kao 滿漢皇輿山河地名考, hereafter abbreviated as the Toponym Study, is a manuscript from the geography section of Manchu and Chinese collection at the National Library of China. The Toponym Study is composed of five thread bound volumes, each meas-

(C) GU Songjie, The Academy for research on Chinese ethnic minority languages, Minzu University of China, 2020 
uring $29.6 \times 18.3$ centimeters, without a case/tao to hold the volumes together. The main text on each half-page is in four parallel rows of Manchu and Chinese text. On the middle of the first, title page or kolophone, of the first volume is the title and to the upper right of this title is written Qianlong gengchen nian 乾隆庚辰年 “the White Dragon year of Qianlong (1760),” while on the bottom left is written Dachun shanxie 達椿繥寫 “compiled by Dachun." The Toponym Study is very well preserved, and in the August of 2017 Fujian People's Publishing issued a photographic reproduction of the work. Until now scholars have neither studied nor cited the Toponym Study, and among the published catalogues of Manchu books it is mentioned four times. However, there are great discrepancies in these catalogs. The "wuchen 戊辰 year" dating in Li Deqi's volume ${ }^{1}$, which is the thirteenth year of the Qianlong period (1748). The volumes ${ }^{2}$ edited by $\mathrm{Fu} \mathrm{Li}$ and Huang Runhua, Qu Liusheng date the manuscript to "the fifteenth year of the Qianlong period" and indicate the year incorrectly as "1760" in parenthesis, since the fifteenth year of the Qianlong period was 1748. If the authors of these catalogs have relied on the title page of the Toponym Study in their dating of this text, they have all dated the work incorrectly except the Beijing diqu manwen tushu zongmu 北京地區滿文圖書總目 (A General Catalogue of Manchu Books in Beijing) with the manuscript dated from "the 25th year of the Qianlong period (1760)".3

The Toponym Study is a compilation of the names of locations in the northern three provinces. Some of the place names include annotations relating to the history of the military conquest of each of the places by Nurhaci and Hongtaiji-and this suggests that this work is related to the 1778 Shengjing Jilin Heilongjiang deng chu biaozhu zhanji yutu 盛京吉林黑龍江等處 標注戰跡輿圖 “Map of Military Deeds in Shengjing, Jilin, Heilongjiang”, hereafter abbreviated as the Map of Military Deeds. In this paper I will follow this clue to reveal the relationship between the Toponym Study and the Map of Military Deeds by a comparison between them, and I will then provide a preliminary analysis of the composition and authorship of the Toponym Study.

\footnotetext{
${ }^{1}$ LI 1933, 51.

${ }^{2}$ FU 1983, 175; HUANG, QU 1991, 225.

${ }^{3}$ Beijing Ethnic Minority Ancient Book Publishing House 2008, 185.
} 


\section{The relationship between the Toponym Study and the Map of Military Deeds}

A comparison between the Toponym Study and the Map of Military Deeds shows that these texts are mostly the same as to the recorded place names, the military achievement annotations contained within, as well as of the order of the entries. The main differences between the two occur in repeated or omitted entries in the Toponym Study, as well as in a very small number of different Chinese characters used in the transliteration of Manchu. Common errors between the two works also appear. I argue that the Toponym Study and the Map of Military Deeds share a common origin, and below I will add an organized comparison of the two in three categories.

\subsection{Place Names}

The Toponym Study is composed of five volumes, and by omitting the text of the first page or first two pages of each volume, there is a total of 2175 place names in the Toponym Study and a total of 2195 place names in the Map of Military Deeds. Imanishi Shunju composed an index of place names for the Map of Military Deeds with a total of 2176 entries $^{4}$; clearly there were omissions. By comparing all the entries in the Toponym Study and the Map of Military Deeds, we can find the repeated and omitted entries in the Toponym Study as well as the entries which appeared in both texts with slight variations. Let's summarize these in the following 3 tables:

Table 1: The repeated place names in the Toponym Study

\begin{tabular}{|c|c|c|c|}
\hline Place Name & $\begin{array}{l}\text { In Toponym } \\
\text { Study }\end{array}$ & Place Name & $\begin{array}{c}\text { In Map } \\
\text { of Military Deeds }\end{array}$ \\
\hline $\begin{array}{l}\text { siowai lii giyamu/xue li zhan } \\
\text { 雪・站 (Snow Place Relay Station) }\end{array}$ & $1-6 b$ & \multirow{2}{*}{$\begin{array}{l}\text { siowei lii jan } \\
\text { giyamun } \\
\text { 雪里站 }\end{array}$} & \multirow[t]{2}{*}{$\begin{array}{l}\text { Second } \\
\text { in the first row }\end{array}$} \\
\hline $\begin{array}{l}\text { siowei lii jan giyamun } \\
\text { 雪里站 }\end{array}$ & $1-7 \mathrm{a}$ & & \\
\hline $\begin{array}{l}\text { barda hoton/ba'erda cheng } \\
\text { 巴尔达城 (Fort Barda) }\end{array}$ & $2-13 b$ & \multirow[t]{2}{*}{$\begin{array}{l}\text { barda hoton } \\
\text { 巴尔达城 }\end{array}$} & \multirow[t]{2}{*}{$\begin{array}{l}\text { Forth } \\
\text { in the second row }\end{array}$} \\
\hline $\begin{array}{l}\text { barda hoton } \\
\text { 巴尔达城 }\end{array}$ & $2-16 a$ & & \\
\hline
\end{tabular}

\footnotetext{
${ }^{4}$ IMANISHI 1959, 222-268.
} 


\begin{tabular}{|c|c|c|c|}
\hline $\begin{array}{l}\text { g'o giya pu/guo jia bao 郭家堡 } \\
\text { (Fort of the Guo family) }\end{array}$ & $2-21 a$ & \multirow[t]{2}{*}{$\begin{array}{l}\text { g'o giya pu } \\
\text { 郭家堡 }\end{array}$} & \multirow[t]{2}{*}{$\begin{array}{l}\text { Fifth } \\
\text { in the second row }\end{array}$} \\
\hline $\begin{array}{l}\text { g'o giya pu } \\
\text { 郭家堡 }\end{array}$ & $2-25 a$ & & \\
\hline $\begin{array}{l}\sin \min \text { tun/xin mintun } \\
\text { 新民屯 (New Agricultural Colony) }\end{array}$ & $2-21 a$ & \multirow[t]{2}{*}{$\begin{array}{l}\sin \min \text { tun } \\
\text { 新民屯 }\end{array}$} & \multirow[t]{2}{*}{$\begin{array}{l}\text { Fifth } \\
\text { in the second row }\end{array}$} \\
\hline $\begin{array}{l}\sin \min \text { tun } \\
\text { 新民屯 }\end{array}$ & $2-25 a$ & & \\
\hline $\begin{array}{l}\text { gahari sekiyen/gahali heyuan } \\
\text { 噶哈哩河源 (Gahari river source) }\end{array}$ & $3-7 b$ & \multirow[t]{2}{*}{$\begin{array}{l}\text { gahari sekiyen } \\
\text { 噶哈哩河源 }\end{array}$} & \multirow[t]{2}{*}{$\begin{array}{l}\text { Third } \\
\text { in the third row }\end{array}$} \\
\hline $\begin{array}{l}\text { gahari sekiyen } \\
\text { 噶哈哩河源 }\end{array}$ & $3-8 \mathrm{a}$ & & \\
\hline
\end{tabular}

Table 2: 25 place names not recorded in the Toponym Study and their corresponding place in the Map of Military Deeds

\begin{tabular}{|l|l|}
\hline \multicolumn{1}{|c|}{ Place Name } & In the Map of Military Deeds \\
\hline liyang šui ho bira/liangshui he 凉水河 (Cold Water River) & First in the first row \\
\hline da yang ho bira/dayang he 大洋河 (Da Yang River) & Second in the first row \\
\hline $\begin{array}{l}\text { niyamniyakū/niyamuniyaku he 尼雅木尼雅库河 } \\
\text { (River of No Mounted Archery) }\end{array}$ & Second in the second row \\
\hline $\begin{array}{l}\text { niowanggiyaha hoton/qinghe cheng 清河城 } \\
\text { (Fort Green Water) }\end{array}$ & Fourth in the second row \\
\hline fakū giyamun/faku zhan 法库站 (Fa Ku Relay Station) & Fourth in the second row \\
\hline sung šan pu/song shan bao 松山堡 (Fort Pine Mountain) & Fourth in the second row \\
\hline tomhoi bira/tuomohui he 托摩辉河 (Tomhoi River) & Fourth in the second row \\
\hline $\begin{array}{l}\text { moši ioi gašan/moshi yu tun 磨石峪屯 } \\
\text { (Millstone Valley Village) }\end{array}$ & Fourth in the second row \\
\hline neihe hecen /kai cheng 开城 (Fort Open Gate) & Fourth in the second row \\
\hline liyooha bira/liao he 辽河 (Liao River) & Fourth in the second row \\
\hline Caiha/cai he 蔡河 (Cai River) & Fourth in the second row \\
\hline horhai pu/he'erhai bao 和尔海堡 (Fort Horhai) & Fourth in the second row \\
\hline $\begin{array}{l}\text { tumet beile i harangga ba/tumote beile suoshu dijie } \\
\text { 土默特貝勒所属地界 (Frontier of the Tumet Prince) }\end{array}$ & Fifth in the second row \\
\hline $\begin{array}{l}\text { karacin beile i harangga ba/kalaqin beile suoshu dijie } \\
\text { 喀喇沁贝勒所属地界 (Frontier of the Harqin Prince) }\end{array}$ & Fifth in the second row \\
\hline $\begin{array}{l}\text { karacin wang ni harangga ba/kalaqin wang suoshu dijie } \\
\text { 喀喇沁王所属地界 (Frontier of the Harqin wang) }\end{array}$ & Fifth in the second row \\
\hline
\end{tabular}




\begin{tabular}{|l|l|}
\hline ci lii ho/qi li he 七里河 (Seven Li River) & Fifth in the second row \\
\hline $\begin{array}{l}\text { g'ao kiyoo giyamun/gao qiao zhan 高桥站 } \\
\text { (High Bridge Relay Station) }\end{array}$ & Fifth in the second row \\
\hline liyan šan pu hoton/fan bao cheng 范堡城 (Fort Fan bao) $)^{5}$ & Fifth in the second row \\
\hline $\begin{array}{l}\text { ho xao men alin/huo shao men shan 火烧門山 } \\
\text { (Mt. Burnt Gate) }\end{array}$ & Fifth in the second row \\
\hline holo bira/heluo he 和啰河 (Holo River) & Second in the fourth row \\
\hline bokori alin/bokeli shan 博科哩山 (Mt. Bokori) & Third in the fourth row \\
\hline obtul hoton/e'butule cheng 额布图勒城 (Fort Obtul) & Fourth in the fourth row \\
\hline hūwaksin šeri/huakexin quan 华克新泉 (Hūwaksin Springs) & Fourth in the fourth row \\
\hline unur bira/wunu'er he 乌努尔河 (Unur River) & Fifth in the fourth row \\
\hline gūrban saikan bira 固尔班河 (Gūrban River) & Fifth in the fourth row \\
\hline
\end{tabular}

Table 3: Names and locations which differ between the Toponym Study and the Map of Military Deeds

\begin{tabular}{|c|c|c|c|c|c|}
\hline \multicolumn{2}{|c|}{ Toponym Study } & \multirow[b]{2}{*}{ Source } & \multicolumn{2}{|c|}{ Map of Military Deeds } & \multirow[b]{2}{*}{ Location } \\
\hline $\begin{array}{l}\text { Manchu } \\
\text { location } \\
\text { name }\end{array}$ & $\begin{array}{c}\text { Chinese location } \\
\text { name }\end{array}$ & & $\begin{array}{l}\text { Manchu } \\
\text { location } \\
\text { name }\end{array}$ & $\begin{array}{c}\text { Chinese location } \\
\text { name }\end{array}$ & \\
\hline ilta šan & yila ta 伊拉塔 & $1-10 b$ & ilta šan & $\begin{array}{l}\text { yila ta shan } \\
\text { 伊拉塔山 (Mt. Ilta) }\end{array}$ & $\begin{array}{l}\text { Second in } \\
\text { the first row }\end{array}$ \\
\hline $\begin{array}{l}\text { ciyan tun } \\
\text { wei }\end{array}$ & qian tun wei 前屯卫 & $1-16 a$ & $\begin{array}{l}\text { ciyan tun } \\
\text { wei hoton }\end{array}$ & $\begin{array}{l}\text { qian tun wei cheng } \\
\text { 前屯卫城 } \\
\text { (Fort Qian tun wei) }\end{array}$ & $\begin{array}{l}\text { First in the } \\
\text { first row }\end{array}$ \\
\hline gas holo & kasi yu 喀斯峪 & $2-8 b$ & gas holo & $\begin{array}{l}\text { gasi yu 噶斯峪 } \\
\text { (Gas Vally) }\end{array}$ & $\begin{array}{l}\text { Fourth in } \\
\text { the second } \\
\text { row }\end{array}$ \\
\hline imsun bira & $\begin{array}{l}\text { yimuxun he } \\
\text { 伊穆逊河 }\end{array}$ & $2-10 a$ & imsun bira & $\begin{array}{l}\text { yimuxun he } \\
\text { 伊木逊河 } \\
\text { (Imsun River) } \\
\end{array}$ & $\begin{array}{l}\text { Fourth in } \\
\text { the second } \\
\text { row }\end{array}$ \\
\hline jakūmu bira & 扎库穆河 & $2-16 a$ & jakūmu bira & $\begin{array}{l}\text { 扎库穆 } \\
\text { (Jakūmu River) }\end{array}$ & $\begin{array}{l}\text { Fourth in } \\
\text { the second } \\
\text { row }\end{array}$ \\
\hline san ca ho & 三岔河 & $2-27 a$ & san ho pu & $\begin{array}{l}\text { 三河堡 } \\
\text { (Fort Three River) }\end{array}$ & $\begin{array}{l}\text { Fifth in the } \\
\text { second row }\end{array}$ \\
\hline
\end{tabular}

\footnotetext{
${ }^{5}$ The Manchu and Chinese writing in the original map do not conform with each other.
} 


\begin{tabular}{|l|l|c|l|l|l|}
\hline $\begin{array}{l}\text { karcin wang } \\
\text { ni harangga } \\
\text { ba }\end{array}$ & $\begin{array}{l}\text { kalaqin wang } \\
\text { suoshu dijie } \\
\text { 喀勒沁王所属地界 }\end{array}$ & 2-34a & $\begin{array}{l}\text { karcin } \\
\text { wang ni } \\
\text { harangga ba }\end{array}$ & $\begin{array}{l}\text { kalaqin wang suoshu } \\
\text { dijie } \\
\text { 客喇沁王所属地界 } \\
\text { (Frontier of the } \\
\text { Harqin wang) }\end{array}$ & $\begin{array}{l}\text { Fifth in the } \\
\text { second row }\end{array}$ \\
\hline inu alin & yinu he 伊努河 & $3-13 a$ & inu alin & $\begin{array}{l}\text { yinu he 伊努河 } \\
\text { (Inu River) }\end{array}$ & $\begin{array}{l}\text { Third in the } \\
\text { third row }\end{array}$ \\
\hline $\begin{array}{l}\text { ookiya } \\
\text { gašan }\end{array}$ & ao'qia tun 奥恰屯 & $4-7 b$ & $\begin{array}{l}\text { ookiya } \\
\text { gašan }\end{array}$ & $\begin{array}{l}\text { ao'qia he 奥恰河 } \\
\text { (Ookiya River) }\end{array}$ & $\begin{array}{l}\text { Third in the } \\
\text { fourth row }\end{array}$ \\
\hline mukturi alin & $\begin{array}{l}\text { muketuli shan } \\
\text { 穆克图哩山 }\end{array}$ & $4-18 b$ & $\begin{array}{l}\text { mukturi } \\
\text { alin }\end{array}$ & $\begin{array}{l}\text { muketuli shan } \\
\text { 穆克图哩山 } \\
\text { (Mt. Mukturi) }\end{array}$ & $\begin{array}{l}\text { Fifth in the } \\
\text { fourth row }\end{array}$ \\
\hline
\end{tabular}

The ten instances in the Toponym Study and the Map of Military Deeds where place names are recorded differently occur in the following circumstances:

(1) When the Manchu names are the same, but the Chinese names are different. For example, ilta šan in the Toponym Study is recorded in Chinese as yila ta 伊拉塔 without the šan which corresponds to the Chinese shan 山; the Map of Military Deeds records this completely. jakümu bira is recorded the same in both, but the Map of Military Deeds lacks the Chinese word he 河 (river) which corresponds to the Manchu bira (river).

(2) When both the Manchu and Chinese names are different. For example, in the Toponym Study a place name is recorded as ciyan tun wei in Manchu and qian tun wei 前屯衛 in Chinese. In the Map of Military Deeds, the Manchu and Chinese both use the word "walled city" with the Manchu hoton and the Chinese cheng 城.

(3) When the Manchu transliteration of Chinese is different. For example, the Toponym Study transcribes the Manchu gas holo with the Chinese kasi yu 喀斯峪 while in the Map of Military Deeps the same Manchu is transcribed into Chinese as gasi $y u$ 噶斯峪. Here the Chinese character used to transcribe the $\mathrm{g} / \mathrm{k}$ sound is different. In another example, the Manchu imsun bira is in both the Toponym Study and the Map of Military Deeds, but here the $\mathrm{m}$ sound is transcribed differently. The Manchu for karcin wang ni harangga ba is identical in both, but the $\mathrm{r}$ sound is transcribed differently into Chinese. The Manchu for mukturi alin is recorded identically in both, but the Chinese character used to transcribe the $m$ sound differs.

(4) When there is an error in the recording. For example, the Toponym Study has duplicate entries for san ca ho/san cha he 三岔河 (Three Branches 
River), and the duplicate entry is a mistake for the san ho pu/san he bao 三 河堡 of the Map of Military Deeds. This place name has a small “口” sign below what is an annotation for military history.

(5) When the two texts have mistakes. Both texts record the Manchu inu alin the same way, and even though the Manchu alin means "mountain," from the graphical depiction in the Map of Military Deeds what should have been yinu shan 伊努山 (Yinu Mountain) is recorded as yinu he 伊努河 (Yinu River). The Toponym Study also records the Chinese name here as yinu he 伊努河 (Yinu River), which I suspect is incorrect. There is also the ookiya gašan which is recorded similarly in both texts (gašan means village and corresponds to the Chinese tun 屯), the Toponym Study records this as ao qia tun 奧恰屯, while the Map of Military Deeds records this as ao qia he 奧恰河. I suspect, the recording of this place name in the Map of Military Deeds is incorrect.

\subsection{Annotation of Military Deeds}

The Toponym Study records a total of 142 military deeds, while the Map of Military Deeds records a total of 144. Those not found in the Toponym Study are:

(1) Niowanggiyaha hoton/qinghe cheng 清河城 (Green River City): Nurhaci attacked and brought the Korean army to submission at this place in the Yellow Sheep year. Here in the year of Yellow Sheep the emperor Taizu (Nurhaci) attacked and submitted the Korean army

taidzu dergi hüwangdi sohon $i$ honin aniya solgo $i$ cooha be ubade afame dahabuha

太祖高皇帝已未年攻降朝鮮兵於此

(2) Gin cang pu/jin chang bao 錦昌堡 (Fort Jinchang): Nurhaci waged a military campaign against the Ming dynasty and took the Fort Jinchang in their surrender in the Black Dog year. In the year of Black Dog the emperor Taizu (Nurhaci) waged military campaign against Ming and took the fort Jinchang

taidzu dergi hüwangdi sahaliyan indahvn aniya ming gurun be dailame gin cang pu be bargiyame dahabuha

太祖高皇帝王戌年征明收降錦昌堡

Except for these two examples, all the other records of military deeds are identical. 
1.3 The annotations in the five volumes of the Toponym Study all follow the pattern where they end in xi yuandi 系原底 (is the original).

The comparison of this kind of place name items to the corresponding entries in the Map of Military Deeds is as follows:

\begin{tabular}{|l|l|}
\hline \multicolumn{1}{|c|}{ Place name and annotation } & \multicolumn{1}{c|}{ Map of Military Deeds } \\
\hline yenggišen alin 英吉伸仙 “仙字照元底” & yenggišen alin 英吉伸仙 \\
\hline niman gašan 尼滿河 “河字系元底” & niman gašan 尼滿河 \\
\hline miyangkeda oforo 密陽喀達鄂佛囉 “喀 ke 系原底” & miyangkeda ofiro 密陽喀達鄂佛囉 \\
\hline alha gašan 阿勒哈河 “河系原底” & alha gašan 阿勒哈河 \\
\hline lalicin ba 拉里拉地 “cin 系原底” & lalicin ba 拉里拉地 \\
\hline kabun bira 喀木河 “bun 木系原底” & kabun bira 喀木河 \\
\hline kuretu noor omo 庫哷圖諾爾鄂博 “系原底” & kuretu noor omo 庫哷圖諾爾鄂博 \\
\hline hūlajin omo 呼拉津鄂諾 “系原底” & hūlajin omo 呼拉津鄂諾 \\
\hline
\end{tabular}

All the place names listed here in Manchu and Chinese are identical to those in the Toponym Study and the Map of Military Deeds. That the author of the Toponym Study, Dachun, uses the term yuandi 原底“original source” in his annotations assures us that the Toponym Study was a copy of another document. Moreover, Dachun discovered that some of the place names were written in his original source incorrectly. For example, Dachun saw that the yenggišen in yenggišen alin/yingji shenxian 英吉伸仙 is correct and without error-but the word alin in Manchu means mountain and corresponds to the Chinese character shan 山, and not the character xian 仙 (immortal). Other examples are the same, niman gašan (Mountain Goat Village) should be transliterated into Chinese as niman tun 尼滿屯 as the Chinese word he 河 (river) corresponds to the Manchu bira (river). Another error can be found in the sound "ke" of the Chinese transliteration given for miyangkeda oforo/ miyang kada e'furuo 密陽喀達鄂佛囉. The sound “ke" should be represented by the Chinese character ke 克, while the character $k a$ 喀 represents the sound “ka." alha gašan/A'leha he 阿勒哈河 should be transcribed to Chinese as A'leha tun 阿勒哈屯. In the laicin part of lalicin ballali ladi 拉 里拉地, the lalicin should be transliterated in Chinese as laliqin 拉裡沁 according to the Transliteration Guide. The kabun in kabun bira/kamu he 喀木 河 should be transliterated as kaben 喀畚, the character $m u$ 木 is used to transliterate the Manchu mu. The omo in kuretu noor omo/ kuletu nuo'er $e$ 'bo 庫哷圖諾爾鄂博 should correspond to the Chinese $e$ 'mo 鄂謨, the $e$ 'bo 
鄂博 used here transliterates the Manchu obo; and in the same way the omo in hūlajin omo/hulajin e'nuo 呼拉津鄂諾 should also be transliterated into Chinese as e'mo 鄂謨 and not e'nuo 鄂諾. Here we can see that the place names recorded in the Map of Military Deeds are not without error. Still, I have no explanation as to why these place name errors went undiscovered as the Map of Military Deeds was completed and published.

In summary of the above, I have shown through a detailed analysis of the place names, the annotations of military accomplishments, as well as Dachun's annotations mentioning a "source text", that the Toponym Study and the Map of Military Deeds contain much of the same content on the place names of the northeast three provinces before the Manchu conquest of China proper and related military annotations - from all of this it is clear that the two texts share a common source.

\section{On the Date of the Text's Completion}

On the colophone of the Toponym Study is written: Qianlong gengchen nian 乾隆庚辰年 “the White Dragon year of Qianlong," which was the 25 th year of the Qianlong reign, or 1760. If this is the date of the text's composition, this would mean that its date of publication would be separated by eighteen years from the Map of Military Deeds discussed above. With the nearly identical contents of the two texts, how should we understand the relationship between these two texts? Was this volume of place names collected and compiled in 1760 and later published as the Map of Military Deeds only after Qianlong's 1775 imperial edict? As the Toponym Study contains no preface, and there are no related materials which we can consult, it is impossible for us to know the compilation process of the Toponym Study. There are, however, several Manchu and Chinese archival documents which shed light on the details regarding the composition of the Map of Military Deeds. Moreover, I have been able to ascertain in detail that the place names and annotations of military history on the Map of Military Deeds are related to the Toponym Study - they arise from the same source. From this I have concluded that the general date of composition assumed for the Toponym Study is incorrect.

In 1775, when Qianlong read through the old Manchu archives, he found that the archives mentioned many place names in Manchuria, but there was no map to check them with. As it should not be that the homeland of his ancestors were without a map, he ordered the Grand Councillors to check the 
old Manchu archives, the Gazetteer of Shengjing and the Venerable Records in detail and write out a list of place names and mailed to the garrison generals of such places as Shengjing, Jilin, and Heilongjiang. Each examined in detail mainly their provincial capitals, but also some other places which were quite a distance from the provincial capitals, and they checked the existence of famous mountains, great waterways, and the places with vestiges of historical persons by their current and former names so as to jointly compile a single map of the three provinces to submit for his perusal. ${ }^{6}$ The Manchu version of this edict included in the Hunchun fudutong yamen dang 琿春副 都統衙門檔 (Yamen Achieves of the Garrison Lieutenant General of Hunchun) ${ }^{7}$

The Map of Military Deeds was drafted by using the ten-row version of Huangyu quantu ${ }^{8}$ as its basis. On May 20, 1776, the Shengjing governorgeneral Hong Shang 弘晌, following the orders given to him, sent a memorial back to the emperor which included a folded map of the three provinces of Shengjing, Jilin, and Heilongjiang with red labels affixed to the places affiliated with Shengjing, pink labels affixed to the places affiliated with Jilin, and white labels affixed to the places affiliated with Heilongjiang. The officials, living in the capitals of each of the provinces, have traversed the areas of the mountains and rivers and completed the detailed investigation and in the areas of the lieutenant banner commanders, provincial commanders, military commandants, brigade commanders, and so on, the place names of the mountains and rivers was sent with invariable meticulousness and repeatedly checked over and over again. Through this large-scale investigation, more than seven hundred place names were found which were not in Huangyu quantu. ${ }^{9}$ The Qianlong emperor decreed:

"Take the draft of the maps to develop a comprehensive map and enumerate the main points of the various items of achievement in Manchu and Chinese annotations on the map in preparation for introspection with respect the achievement of our ancestors and pass through the ages." 10

${ }_{7}^{6}$ Qing gaozhong shilu 1986, vol. 21, 316.

7 Hunchun fudutong yamen dang 2006, vol. 10, 27-29.

${ }^{8}$ There are many versions of the Huangyu quantu published during the Qianlong period, with the earliest published in 1761 known as the Neifu yutu 內府輿圖 (Imperial Household Department Map) or the Qianlong shisan pai tu 乾隆十三排圖 (Qianlong Thirteen Row Map). Moreover, a ten-row version of the map was published between the years 1761 to 1775 .

${ }^{9}$ Grand Council copied Manchu archives 03-0187-2680-021, 03-0187-2681-048.

${ }^{10}$ Imperial Household Department memorial 05-08-030-000007-0033. 
The leaders of this map's composition, the ministers Šuhede (舒赫德), Agūi (阿桂), and Ingliyan (英廉), sent their suggested format of the annotations of military deeds and their suggestions to enlarge the dimensions of the map - they sent the following memorial in June, 1776.

We your ministers have humbly checked the total ten rows of the Huangyu quantu and found that the places of Shengjing and so on stop after a bit over two rows. Its square space is limited and besides listing place names it is impossible to have any annotations. For the places such as Shengjing which are contained inside, we will separately draft a complete map to annotate all historical achievements in detail. Yet, we have found through our respectful investigation of the Veritable Records that the various achievements of the past were numerous. Nevertheless, that which we take to annotate the main points of must also not be oversimplified. If for every single place name, we are to annotate one historical achievement, the lines of Manchu and Chinese texts would be too numerous, and it would be difficult to expand the size of the map. Now, we your ministers have thought carefully on this matter, all the records of achievement of the place names in the map will be narrated with their year and month and their main points indicated under the place names. For example, there is a place called Mt. Sarhū with the annotation 'On the third month of the fourth year of the Tianming reign four-hundred and seventy thousand soldiers of the Ming came to attack. The Taizu emperor led sixty-thousand soldiers to this place.' All the place names with historical achievements in the map imitate this style in their annotations in using Manchu and Chinese characters. ...Again, besides the formerly accepted decree which was handed over to the generals of such places as Shengjing and has been supplemented with the discovery of a total of sevenhundred place names to be added to the new map, the old map will also be handed over to Department of Cartography for their detailed addition of the ten rows included within the print. This combination will be declared to you in a respectful memorial. ${ }^{11}$

Only at this time did the format for the inclusion of military deeds appear, and over 700 place names were newly added to the map. Thus, in the span of two years the map project was finally wrapped up. On May 20, 1778, the Department of Cartography in the Workshop of the Imperial Household submitted a memorial requesting compensation for their work. ${ }^{12}$ By that time

\footnotetext{
${ }^{11}$ Ibid.

${ }^{12}$ Memorial 05-08-030-000007-0033.
} 
Šuhede had already passed away in 1777, so Agūi was the head minister in charge of the project. Agūi led Fulong'an, Ingliyan, and Heshen to memorialize respectfully:

Concerning the matter of our respectful presentation of a territorial map, we, your ministers, have respectfully received the imperial edict to handle the matter of the territorial mapping of Shengjing, Jilin, and Heilongjiang. We have sent drafts of the map in succession, and checked the place names in the Veritable Records and the Old Manchu Achieves about historical achievements related to the beginning of the great enterprise to be compiled into annotations. We respectfully received the benefits of your majesty's instructions and followed your instructions to handle this matter to expand the map into five rows and unite the two-thousand three-hundred and thirteen places on the map with a hundred and forty-four annotations which we respectfully recorded in both Manchu and Chinese. The original edict from your majesty was placed at the begining of the map. Now we have finished the drafting and respectfully submitting the territorial map for your inspection. We humbly wait for your orders. We will hand over the map to the Department of Cartography so that it may be engraved for woodblock print and decorated. We respectfully send it to be kept in the inner place and in Shengjing, so that it may be passed down through the ages. Thus, we have issued with respect a single copy of the map to the generals and lieutenant-generals in such places as Shengjing as well as to the various yamen for storage. With this we respectfully submit our memorial. Submitted in memorial on the 26th day of the 6th month of the 43rd year of the Qianlong. ${ }^{13}$

In this way the map was finally handed over to the Wuying dian 武英殿 (Hall of Military Excellence) for a woodblock print engraving to be made in the second lunar month of $1779 .{ }^{14}$ In 1782 the Qing court bestowed a reward on the nobility and officials who participated in the drafting of this map. Unfortunately, by that time Šuhede, the leader, and the garrison general Hong Shang had already passed away and were unable to receive their rewards. ${ }^{15}$

In light of the aforementioned details of the compilation process of the Map of Military Deeds, we can know that the 2000 additionally recorded place name entries in the Toponym Study were collected after Qianlong's imperial edict of 1776, and 700 of these entries were not included in any

\footnotetext{
${ }^{13}$ Imperial Household Department memorial (micro-film archives).

${ }^{14}$ Ibid.

${ }^{15}$ Memorial 03-0178-098.
} 
previous territorial maps and were only added with the progress of the Map of Military Deeds. Except for the two entries of Qinghe cheng 清河城 and Jinchang bao 錦昌堡 which are not included in the Map of Military Deeds, all the entries in the Toponym Study also appear in the Map of Military Deeds. Only in 1777 did the ministers of the Grand Council who led this project determine the format of the annotations. The Map of Military Deeds was completed in summer of 1778 and was printed in spring of 1779. If the Toponym Study was written in 1760, the Qianlong emperor would not have 15-years later ordered again for a place name study of the northeast, and then spent another two or three years of effort and money to produce the Map of Mililtary Deeds. Thus, the Toponym Study could not possibly have been written in 1760 as is indicated on its title page. This book, perhaps, is a volume of place names used during the 1776-1779 period of the compilation of the Map of Military Deeds, or it is also possible that it was composed after 1779 as a handwritten copy of the Map of Military Deeds.

\section{Concerning Authorship}

On the colophone page of the Toponym Study to the left of the title is indicated, "written by Dachun", so there should be no doubt that Dachun was the author of this volume. Moreover, we can find four figures with a name pronounced as and written with the characters “Dachun 達椿," and two of the figures were successful candidates in the highest imperial examinations who held positions in the imperial court. The other two figures were local government officials - one was the military commandant of Taiyuan, later promoted to be the garrison lieutenant general of Shengjing, then transferred to be the garrison lieutenant general of Jingzhou. The other held the position of garrison lieutenant general of Guangzhou.

Biographical information about the Dachun who became a jinshi (presented scholar) in 1760 appears in the Draft History of the Qing:

Dachun's courtesy name was Xiangpu and his lineage name was Wusu. He was a Manchu of the Bordered White Banner. He became a jinshi, successful candidate in the highest imperial examination in the 25 th year of the Qianlong period, and was selected to the Hanlin Academy. Upon his release from the Hanlin Academy he was accepted to the Ministry of Revenue, where he took an untitled position. He had once been an imperial tutor, academician, performed the libations at the imperial academy, deputy intendent to the House of the Crown Prince, and presided over the Court of Judicial 
Review while being in the Hanlin Academy. In the 29th year of the Qianlong period he entered into service for the emperor in the school for the emperor's sons where they read fully in the Complete Library of the Four Branches (by the 37th year of the Qianlong period). For his hard work he was promoted to be assistant minister of the Ministry of Rites, while concurrently a banner vice-commander. In the 44th year of the Qianlong period, he committed a crime by braking the roof of the Institute of Interpreters and Translators (which was the hotel for envoys from tributary countries), when an envoy from Korea was killed. He was deprived of his title, but remained in office. In the 54th year of the Qianlong period he was demoted to be an academician of the Grand Secretariat. Dachun entered the imperial court. He did not get along with Heshen, and several times pointed out his shortcomings. He was dismissed from his office due to neglect. Yet, he remained to devote his efforts at the School of the emperor's sons. He was sought out and conferred the title of academician at the Hanlin Academy, yet again due to his performance in the great internal examination, he was demoted and criticised. The Jiaqing emperor was aware that, he had been treated unfairly, so in the 4th year of his reign he issued an edict to confer upon Dachun a position of an academician in the Grand Secretariat and a concurrent position of a lieutenant banner commander. He had experience as an assistant minister in the Ministry of Rites and the Ministry of Personnel while also being a chancellor of the Hanlin Academy. He was promoted to be the premier president of the metropolitan Court of Censors and a provincial military governor before being transferred to become a high official of the Ministry of Rites. In the 6 th year of the Jiaqing period, he administered the metropolitan examination. He passed away in the 7 th year of the Jiaqing period. ${ }^{16}$

Compared with the other three figures, I believe that the Dachun mentioned above is the author of the Toponym Study. The basis of my inference is:

1. in 1775 he presided at the Court of Judicial Review, and along with Heshen and others he held office in the same imperial court, as all of the officials such as Heshen, who had undertaken the drafting of the Map of Millitary Deeds, and he had the opportunity to see the Map of Military Deeds;

2. he had once read through the entire Siku quanshu (Complete Library of the Four Branches) of which the revised edition later included the Map of Military Deeds, so Dachun would have had the opportunity to see all kinds of documents including the Map of Military Deeds;

\footnotetext{
${ }^{16}$ ZHАO 1977, Vol. 37, 11279-11280.
} 
3. in 1764 he entered the school of the emperor's sons where he instructed for many years. In 1802, he wrote a memorial to the Jiaqing emperor at the time when he became critically ill, "I have worked part time in the esteemed study for twenty-eight years, and every day when I waited upon you, I received your imperial favor." ${ }^{17}$ In this way, this particular Dachun had a greater opportunity than the other three Dachun to consult the Map of Military Deeds and have his colleagues show him territorial maps.

In short, this Dachun had a greater opportunity than the other three Dachun to directly consult the Map of Military Deeds and to create the Toponym Study. Also, my best guess is that the date indicated on the Toponym Study's title page the “Qianlong gengchen nian 乾隆庚辰年” (1760) refers to the year when this Dachun became a jinshi (presented scholar). As there are no resources which can be further consulted to prove this, this remains only my conjecture.

\section{Conclusion}

This paper has through a comparison of Man-Han huangyu shanhe diming kao (Imperial Territory Mountain and River Toponym Study in Manchu and Chinese) to the Shengjing Jilin Heilongjiang deng chu biaozhu zhanji yutu (Territoral Map of Military Deeds in Places Such as Shengjing, Jilin, and Heilongjiang), inferred that these two works arise from the same source. It is very unlikely that this work was composed in the "Qianlong gengchen nian 乾隆庚辰年” (1760). During the Qing period, Manchus were referred to only by their given names without their family names, and there were many Manchus who had the same name. I hypothesize that the author of it was the Dachun who had become a jinshi in 1760.

Additionally, the first page or the first two pages of the main text in each volume of the Toponym Study are without a common name, and the vocabulary like this adds up to altogether 70 entries. Of these entries, 24 have annotations which explain that the terms correspond to either Manchu or Mongolian vocabulary - for example, the entry for "janggiya" is “zhangjia 張家 in Mongolian a knot (jiezi 結子) is called zhangjia 章家." The inclusion of these entries which do not have a common noun is the unique characteristic which differes this work from the Map of Military Deeds, and it could be

\footnotetext{
${ }^{17}$ Grand Council copied Chinese archives 03-1464-047.
} 
said that this is the "study" (kao 考) part of this work. As to why the author had chosen to list seventy of the terms independently among the numerous toponyms and only make annotations for a third of the entries-we cannot know.

The huangyu (imperial territories) in the title the Huangyu shanhe diming kao (A Study of Mountain and River Toponyms of the Imperial Territories) refers to the imperial domain. This huangyu, is however, not the same as the Huangyu quantu (Complete Map of the Imperial Territory). It is widely known that the Huangyu quantu is a map of the national territory of the Qianlong period. Yet, the content of this only refers to the Three Eastern Provinces (Heilongjiang, Jilin, and Liaoning). This area is the birthplace of the Manchu people, and the goal of the Qianlong drafted Map of Military Deeds was to allow for his descendants to commemorate their ancestors and inscribe the deeds of the conquest of the northeast before the Manchu's had established Beijing as the capital of the Qing. At the same time, Qianlong wanted to investigate the mountains and rivers of all sizes in the northeast. Thus, the huangyu in the title of this book refers to the state territory of the Qing before it had conquered China proper.

\section{Reference}

Beijing diqu manwen tushu zongmu 2008: 北京地區滿文圖書總目 [A General Catalogue of Manchu Books in Beijing]. Ed. by Beijing Ethnic Minority Ancient Book Publishing House. Shenyang: Liaoning minzu chubanshe.

Dairen mantetsu toshokan shozō 'Seikyō Kitsurin Kokuryūkō-tōsho hyōchū senseki yozu 1935: 大連満鉄図書館所蔵「盛京吉林黑龍江等處標戰績塞圖」 [The 'Map of Military Deeds in Shengjing, Jilin, Heilongjiang' stored in the Dalian Manchurian Railroad Library collection], Published by Japanese Manchu Cultural Association.

Fu Li 1983: Shijie manwen wenxian mulu chubian 世界滿文文獻目錄初編 [A Preliminary Catalogue of Global Manchu Materials], Published by China's Ethnic Minorities' Ancient Characters Research Association, Beijing

HuANG Runhua, Qu Liusheng 1991: Quanguo manwen wentu tushu ziliao lianhe mulu 全國 滿文圖書資料聯合目錄 [A Union Catalogue of Manchu Materials in China]. Beijing: Shumu wenxian chubanshe.

Hunchun fudutong yamen dang 2006: 琿春副都統衙門檔 [Yamen Achieves of the Garrison Lieutenant General of Hunchun], Frontiers of Chinese History and Geography Research Center and the First Historical Archives of China jointly compiled. Guilin: Guangxi Normal University Publishing.

IMANISHI Shunju 1959: Seikyō Kitsurin Kokuryūkō-tōsho hyōchū senseki yozu sakuin [An Index to the The 'Map of Military Deeds in Shengjing, Jilin, Heilongjiang'], Toho 
gaku kiyō [Monumenta Orientalia]. Ed. by Department of Eastern Studies of the Tenri University Oyasato Research Institute, vol. 1, 220-268.

Li Deqi 1933: Manwen shuji lianhe mulu 滿文書籍聯合目錄 [Union Catalogue of Manchu books in the National Library of Peiping and the Library of the Palace Museum], Published by the National Library of Peiping and the Library of the Palace Museum, Beijing.

Li Xiaocong 1996: Ouzhou shoucang bufen zhongwen gu ditu xulu 歐洲收藏部分中文地圖 敘錄 [Commentary on a Portion of Old Chinese Language Maps in Europe]. Beijing: Guoji wenhua chuban gongsi.

Neige tiben 內閣題本 [Routine Memorials of the Grand Secretariat], 軍機處錄副奏摺 [Grand Council copied archives].

Neiwufu olang'a 內務府檔案 [Imperial Household Department memorials] of the Qianlong reign preserved in the First Historical Archives of China.

Qing gaozhong shilu 1986: 清高宗實錄 [the Qianlong period Qing Veritable Records]. Beijing: Zhonghua shuju.

Qing neiwufu zaobanchu yutufang tumu chubian 1936: 清內務府造辦處興圖房圖目初編 [First Edition of the Catalog of Maps by the Artisans of the Qing Imperial Household Department], Beijing: National Beijing Palace Museum Publishing.

Shengjing Jilin Heilongjiang deng chu biaoji zhanji yutu 1981: 清初史料叢刊第十四種 [The fourteenth series of historical materials in the early Qing Dynasty], Published by the History Department of Liaoning University, Shenyang.

ZHAO Erxun 1977: Qingshi gao 清史稿 [Draft History of the Qing]. Beijing: Zhonghua shuju. 